\title{
Good Trouble: Post-Tenure Interruptions to Our Academic 'Routines'
}

\author{
Nick Tobier
}

\begin{abstract}
As a public artist and designer, I construct spaces that connect people and ideas. The social spaces I create challenge our traditional ways of thinking, knowing, and experiencing one another and our cities. This piece presents a resistance to preset disciplinary values and a recognition that exponential rather than incremental change in an urgently evolving filed demands knew form and language. Working at what might be described as the margins of a field within a discipline that is itself often at the margins of a University necessitates both deliberate articulation and responsibility to translate less orthodox practices, off-center inquiry, ways of knowing and outputs in the tenure and promotion process. This pieces challenges us to see the civic work we do as good work, and when our good work serves as an interruption to the existing status quo of the academy, then this good work serves to bridge the academy to cities in more meaningful ways.
\end{abstract}

Keywords: post-tenure reflection; civic engagement; faculty roles and rewards; art and design; institutional margins; reciprocity; social spaces

\section{Introduction}

In my discipline of Art and Design, and my roles as a professor and civic engagement institutional leader, there is, for me, both the good work of problem solving that we do, and the good trouble we create. We accomplish this by continually learning to understand and speak the languages of our community partners while sharing our own. Through this sharing, we build social justice exemplars that live into our institutional rhetoric that frequently promises to act in the public good. This example, I hope, gives some sense of how my work as an artist and designer appears as an interruption:

Not too long ago I walked in a uniform topped by a white conductor's hat and gloves with a small cadre of willing transportation advocates down the center of Woodward Avenue in Detroit. Three lanes of vehicular traffic on one side heading north, 3 lanes of traffic on the other side heading south, we caused some trouble to the routine traffic as we walked in between the yellow lines, and collectively made a 'train' composed of ladders, mop buckets, yellow umbrellas, dry ice, a leaf blower and two shovels. Along the way, our train paused to pick up passengers.

Causing trouble means that my role as a professor of art and design and as an institutional civic engagement leader is to provoke the introspection and questioning that comes with good trouble. The good trouble we can cause helps to interrupt our traditional academic routines and our ways of thinking about and doing our teaching and research as community engaged faculty members and administrators. In this piece, I will share some examples of the "trouble" I cause through my 
work. This will help us think more critically and creatively about public interruption as a radical social strategy to bring awareness to and advance change in our communities.

New Civic Engagement

In my current role at the University of Michigan, in addition to my research and teaching, I serve as the Edward R. Ginsberg Senior Counsel to the Provost on Faculty Civic Engagement to advance civic and community engagement. It is hard for me to fathom that I find myself in this role - that as a self-defined marginal practitioner at a small marginal unit at a big research University I was selected for a position to advocate for colleagues, programs and priorities in civic engagement at a University-wide level. This is a position I grew into, or maybe, the where University and I grew together.

I owe a debt to Bryan Rogers, a supportive Dean who valued off-center inquiry of all sorts. He especially practices that co-mingled "inside" and "outside" engagement. Dean Rogers encouraged me to seek allies and supportive colleagues outside the department as soon as I arrived at Michigan. It would be misleading to say that this has all been strategic, and it would be less than useful to ascribe it to coincidence. More accurate is to suggest that we each seek out our best allies in the people who believe in the intellectual and creative inquiry we have as citizenscholars. Among the aspirations I have for my current roles (as senior faculty with the safety of tenure and as an administrator) is to create spaces and connections that support and encourage my colleagues' initiatives, ideas and efforts. They are seeking to forge paths of community partnership, as well as practices and pedagogies of connection and social justice and the resulting creative scholarship of surprising or unexpected form. It is critical for me in this role to navigate the institutional context of the University while hewing true to my core values as instigator of good trouble. There are daily challenges to help scholars navigate questions of promotion and tenure expectations, the demands of scholarship, unequal power and resource distributions with community partners, and remembering the very human reasons why many of us came to this work in the first place. Yet I use my experience, resources, and position within the institution to advance of collective commitments to civic and community engagement.

My work and interest in public, street-side projects is informed by years after college working in the world - as a hotel doorman, as a construction worker, and as a landscaper and later, landscape designer. Each of these experiences contributed to my understanding of the roles of work in constructing public places. Whereas I spent hours changing my white gloves to wave for a taxi in Philadelphia or carry a bag, such ceremonial attention rarely graces those who wait hours for a bus, or a train. In my work as a door attendant, I learned to love the ceremony of my work and the camaraderie of our uniformed corps. I loved being part of a team that is so often at odds with the individual accolades and achievements that fuel our meritocracies. My work explores the impact of art and social practices, the blurring of art and everyday life, and the role of an artist in society. I create public art as a gesture of utility, civility, and encouragement of relationships with others. 


\section{Detroit Local}

My work on the train project, Detroit Local - a street-side appearance project in response to a new streetcar line - navigated many of these questions, both literally and metaphorically. The train was a response to a new streetcar line, funded by a billionaire and serving the already wellserved downtown core of Detroit. This inequity of resources irritated me along with countless others. Our train project picked up where the new line stopped, calling attention to the uneven development of the city and the confluence of private interests, development and access to transit.

These appearances are and have been the context of my work in my discipline - Art and Design. As my work, which I describe as public construction, ${ }^{1}$ exists outside of my field's traditional metrics of measurement - exhibitions in galleries or museums - I have found it useful to continually define my own terminology both as a reflective exercise, and as a guide for my colleagues and peers to see the context, aspirations and relative merits of these efforts. There is, lurking in these definitions, both a resistance to preset disciplinary values and a recognition that exponential rather than incremental change in an urgently evolving field demands new form and language. I work at what I might describe as the margins of a field within a discipline that is itself often at the margins of a University. This necessitates both deliberate articulation and responsibility to translate less orthodox practices, processes and outputs in the tenure and promotion process.

Presenting my work for review to my colleagues, many of whom fall within the rubrics of traditional artistic practice, has been a continual growth process. At times, I admit, I have chafed under the weight of what seem to be so many concurrent (but not concentric) systems of growth. On the one hand, I have my professional obligation to the disciplinary fields. On the other hand, those accomplishments lie embedded in the lives and rhythms of communities and partnership. These two competing poles - one bent on individual achievement and accolades, and the other grounded in collective action and consensus building - create the contradictions with which civic engagement advocates contend. We learn the mismatch of academic time and the rest of the world. While we live by the semester, the year, or the summer hiatus, our partners are on 24/7 time, and thus our urgency of conference deadlines or grant proposals is at odds with their daily lives.

In Detroit, the gathering of the train's participants took nearly two years of building trust, forging alliances, and sharing insights along with fashioning props and uniforms. Through this process, I employed activist strategies to realize public works of art and design. Such projects lie equidistant from a place-based art and design and what I call experimental urban planning: the signature ephemera of parades or block parties intersect with the cultural collisions occurring when these coincidental communities collide with intentional actions. This extended process is core to civic engagement, not to find a solution but to be present and patient with working to forge a collective response. Yet in terms of the measures in our tenure and promotion processes, all of this remains at the margins. The video document of Detroit Local, a 3-minute edited film, has appeared at film festivals and as part of exhibitions around the world. The act of translating the intricate process of building relationships, negotiating questions of representation and power dynamics in the transformation of public space is in Detroit was validated by a film festival in Tokyo. 


\section{Field of Our Dreams}

I had been working with students at Earthworks Urban Farm in Detroit, and eating our meals as guests at the adjacent Capuchin Soup Kitchen, which runs the farm. At a table in the lunchroom, I became friends with Keith Love and Warren Thomas, who are regular guests of the kitchen. Among the things we shared was an interest in doing something to enable access to the produce we were fortunate enough to find. The F.O.O.D. project was born of these conversations, and the persistence of Keith and Warren, along with Greg Bostic and EarthWorks staff, Gwen Meyer and Lisa Richter.

Field of Our Dreams (F.O.O.D) was a project where the relationship building process extended far beyond any academic accumulations. F.O.O.D. was a mobile produce business that operated on Detroit's Lower East side, on Tuesdays and Thursdays at street corners, housing projects, adult care facilities. For two years, when friends asked what I was working on, I told them that I have been selling fruits and vegetables on street corners in Detroit. The next question was, usually, "what are you working on as an artist?" I had served hot chocolate from an embroidered and upholstered cart, and built a portable picnic table for New Yorkers eating from food vending carts. F.O.O.D. aligns with these earlier projects, both within the rubrics of relational aesthetics or social practice and in the spirit of providing a service as part of a cultural inquiry. F.O.O.D. means many things to me and asks many questions for me about the impact of art \& social practices, the blurring of art and everyday life, and the role of an artist in society.

F.O.O.D. showed up 2 days a week, for regularly scheduled stops on the lower East Side, one of the many neighborhoods in Detroit that are food deserts - for most residents, this is their only access to fresh food. Not to mention the social aspect of being able to gather at a corner and talk with neighbors and strangers a like. Through its regular and recurrent presence, F.O.O.D. was sometimes a viable business, as well as tangible evidence that individual action and motivation have the ability to respond to pressing social needs with innovative, appropriate and interesting responses with critical and interrogative design process and projects.

At the F.O.O.D. truck, I was a staff member working for the business, although my partner most often introduced me as an artist. This always gave me good pause to reflect on practices I value and aspire to, as well as those about which I have questions. I have been the form giveruniforms, precedent study and inspiration for envisioning small markets around the world, business cards, web site, display, infrastructure design and construction. These are artifacts of building relationships between my co-workers, and with the people who come to buy from us. Once, I overheard Keith Love describing me as an artist to a customer who asked, "What's that dude doing here?" "His work," Keith continued, "is that he gives shit away." What I got from the opportunity of being part of F.O.O.D., to truly build complex relationships is far more than I could have anticipated through any other project, including insight, commitment to others and challenges to reflect on and respond to.

\section{Marvelous Guests}

The clothes dryer is turning. Slowly, the contents rotate 360 degrees clockwise. And then again. For ten minutes, or until another coin is inserted. Such is the elegant monotony of 
a laundromat, as each machine perfects its movements over set intervals. Next to the wall of dryers, a ballet dancer performs a stretching sequence. Extending an ankle and rotating the foot. First clockwise, 360 degrees, over and over. Then again.

In my roles as an artist and designer and now, professor at the University of Michigan, I see certain parallels in an ongoing project, Marvelous Guests. Aspiring to recognize both the inherent messiness of differences, Marvelous Guests is an interrelated series of delegated performances lending new working conditions and meanings to several trades. To this end, we invite professionals to conduct their business in unusual locations - as a guest. Each encounter produces its own forms of communication on location. The relationship between guest and host as dynamic, and not without friction as each adjusts to the other. Much like an oyster, the guest is perhaps the catalyst who needs a host in order to make a pearl. An irritant at first, a persistent question, but ultimately, a marvelous new relationship evolves. I hope to continue to be an irritant, and to be irritated at the same time.

By taking activities out of their familiar environment, we share a chance to see something beautiful, poetic, possibly absurd, precious or powerful. At the same time, the environment offers a new context for everyone to recognize the implications of what occurs rather unremarkably on any other given day.

\section{Conclusion}

Negotiation of the artist's (or any discipline) presence in someone else's territory is one of the key components of this work and of civic engagement. I, the individual, am responsible for interjecting this content and its specific aesthetic concerns into a public/quasi-public space as a guest of those places. Beginning with this first layer of communication, participation with me the artist as a Guest starts right away. Can I work with you?

I was tremendously fortunate to arrive at the School of Art and Design (now Penny W. Stamps School of Art and Design) under the leadership of then-dean Bryan L. Rogers. Dean Rogers had been a chemical engineer before becoming an artist, and his modus operandi was to welcome friction, and to encourage exploration. His support encouraged me, along with scores of my colleagues and our students, to see our roles as not bound by disciplinary convention but spurred by good trouble-making. I cannot overstate the role of a supportive Dean, both in the tenure and promotion process, and in personal growth. One of my quests currently as a now senior faculty member and as Senior Counsel to the Provost is to offer the support and encouragement for our colleagues striving in civic engagement teaching and research to continue to ask rude questions about our roles and cause good trouble. The APG (Artist Placement Group) Manifesto, 1980 reads, "Negotiations are contingent upon both participants having this understanding and a mutual confidence."

In what I hope is part of a legacy of Great Britain in the 1970's, idealistic groups and practitioners around The Artists' Placement Group (APG) advocated that artists can and should take part in projects and processes in which creative thinking and energy take precedence over surface manipulation or pure form giving. The APG model - to integrate artists into Sixties' British businesses and corporations_-proposed a structural challenge at an institutional level, 
where the artist was a negotiated presence. I often think similarly of my work in the University and in communities. I value this negotiated presence. It suits my personality (I would like to ascribe it to being a Libra, but that may be a stretch) as someone who values social complexity and dynamism over clear delineation and linear processes and who savors conversation over finding information.

Additionally, I find it is an honest and effective place to be for civic engagement. It recognizes that we should never be presume our positions, but rather, continually negotiate them. Shall we be an integral presence, or a long-term guest? "Guest worker" often connotes a non-resident alien allowed to work for a finite period. That is, typically, why a guest worker seeks to avoid trouble, and precisely why I believe that those of us in a position of relative security must continually seek out, and inquire into, new problems. Problems, like trouble, put something in the way for us to figure out how to respond. Thus my conversation with David Ross at Burt Road Muffler negotiating the appearance of a bagpiper by the car vacuums as with Captain William Boynton of the Grand River Boat Cruises (who hosted a goldfish in a bowl), were problems I raised. My role as an artist and Senior Counsel demands communication across disciplines, amongst a broad range of creative ideas and in communication with a broad range of contexts. I offer each partner an opportunity to say no, to ask questions, to suspend disbelief or say "why not?"

Problems are roadblocks that give us pause to reevaluate, for our partners and ourselves, as well as for skeptics. Like the "train" that appeared on Woodward Avenue, we have a line willing to enter traffic and create an image of a possible future. University people come as problem creators, however much we like to believe we are offering expertise, resources or solutions. For our department chairs, we offer problems in our different forms of practice. That, for me, is the good hard work we have chosen to do. The good trouble we create by continually learning the languages of our community partners while sharing our own, we build social justice exemplars that live into our institutional rhetoric that frequently promises to act in the public good.

There is, of course, the threat of expulsion from the University, or displeasing assignments, direction or cautions from administrators who do not yet see the value of civically engaged pedagogy and practice. To be fair, there are expectations to uphold that are not secrets - that creation of new knowledge through scholarship and/or creative practice is the University's mission. For instance, if I were to re-examine my entry to the University of Michigan, a tier 1 research campus, I might have paused to reflect on the expectations and trade-offs accompanying the mission and the opportunity. In addition to a supportive Dean, I was able to find my aspirational academic allies here, in particular the Ginsberg Center and Arts of Citizenship, where I first met with and worked with supportive and dynamic colleagues from History, Urban Planning, and Dance. The camaraderie and mentorship shared by Charlie Bright, Margi Dewar, Kamilah Henderson, Robin Wilson and AT Miller were invaluable as they formed a community of practice that encouraged me to continue to seek and value reciprocal partnerships within and beyond the University, and to see good trouble on the margins as good work. As a senior faculty member with the safety of tenure, I now find myself as a creator of spaces to advance our collective good trouble. 


\section{References}

Artists' Placement Group. (1980). Manifesto, 1980 edition. Retrieved from

http://www.darkmatterarchives.net/wp-content/uploads/2011/02/FINAL_Manifesto_APG.pdf 


\section{Author Information}

Nick Tobier

Professor, Art and Design

School of Art and Design

University of Michigan

2000 Bonisteel Blvd.

Ann Arbor, MI 48109-2069

Email:nicktob@umich.edu

Telephone: (734) 936-0697

Pr. Tobier studied landscape architecture at Harvard's Graduate School of Design and subsequently worked in professional practice in Boston and New York. He was assistant professor at the School of Art at Alfred University. He is now a full professor at the University of Michigan Penny W. Stamps School of Art \& Design. In addition, he serves as Senior Counsel to the Provost on Civic Engagement. In his current research and teaching, Pr. Tobier conducts collaborative projects in the public realm, including partnerships with furniture designers, bakers, farmers; critical and celebratory involvements between artists, designers and broad communities; and a commitment to lasting partnerships working with creative individuals and communities from Detroit to Ishinomaki.

${ }^{1}$ I mean both a location (public) and an ideological compass (public/civic). I mean material, sociocultural, structural and economic (construction); I also mean process (the act of construction is in formation.) 